\title{
Growth response to ozone of annual species from Mediterranean pastures
}

\author{
B.S. Gimeno*, V. Bermejo, J. Sanz, D. de la Torre, S. Elvira \\ Ecotoxicology of Air Pollution, CIEMAT (ed. 70), Avda, Complutense 22, 28040 Madrid, Spain
}

\begin{abstract}
"Capsule": The therophytes from dehesa acidic pastures of central of the Iberian peninsula present a great sensitivity to ozone, as derived from growth- and biomass-related variables.
\end{abstract}

\begin{abstract}
Ozone $\left(\mathrm{O}_{3}\right)$ phytotoxicity has been reported on a wide range of plant species. However, scarce information has been provided regarding the sensitivity of semi-natural grassland species, especially those from dehesa Mediterranean grasslands, in spite of their great biological diversity and the high $\mathrm{O}_{3}$ levels recorded in the region. A screening study was carried out in open-top chambers (OTCs) to assess the $\mathrm{O}_{3}$-sensitivity of representative therophytes of these ecosystems based on the response of selected growthrelated parameters. Three $\mathrm{O}_{3}$ treatments and 3 OTCs per treatment were used. Legume species were very sensitive to $\mathrm{O}_{3}$, because $78 \%$ of the tested species showed detrimental effects on their total biomass relative growth rate (RGR) following their exposure to $\mathrm{O}_{3}$. The Trifolium genus was particularly sensitive showing $\mathrm{O}_{3}$-induced adverse effects on most of the assessed parameters. Gramineae plants were less sensitive than Leguminosae species because detrimental effects on total biomass RGR were only observed in $14 \%$ of the assessed species. No relationship was found between relative growth rates when growing in clean air and $\mathrm{O}_{3}$ susceptibility. The implications of these effects on the performance of dehesa acidic grasslands and on the definition of ozone critical levels for the protection of semi-natural vegetation are discussed.
\end{abstract}

Keywords: Relative growth rate; Dehesa; Screening; Therophytes; Critical levels

\section{Introduction}

Semi-natural vegetation is frequently exposed to elevated ozone $\left(\mathrm{O}_{3}\right)$ concentrations throughout Europe (EMEP, 2002) which can adversely affect the most sensitive species, inducing changes in the floristic composition of plant communities (Ashmore and Ainsworth, 1995; Barbo et al., 1998; Fuhrer et al.,
1994). However, limited information has been provided regarding the sensitivity of these ecosystems to $\mathrm{O}_{3}$ as has been recently reported in the last UN/ECE (United Nations Economic Commission for Europe) workshop held to define ozone critical levels for plant protection (Ashmore and Franzaring, 2003). As a result, $\mathrm{O}_{3}$ critical levels for semi-natural vegetation are poorly defined, especially for the Mediterranean area where high $\mathrm{O}_{3}$ concentrations have been recorded.

Few studies have been carried out aiming to evaluate the $\mathrm{O}_{3}$ sensitivity of Mediterranean grassland species. For instance, Velissariou and Davison (1994), Madkour and Laurence (2002) and El-Khatib (2003) reported the great sensitivity of several local Greek and Egyptian 
cultivars of fodder crops, the Leguminosae species Medicago sativa and Trifolium alexandrinum being the most sensitive ones of those assessed. More recently, Bermejo et al. (2003) and Gimeno et al. (2004) have carried out experiments focused on the therophytic pastures from dehesa acidic grasslands of the central Iberian peninsula. These are valuable ecosystems presenting a great biodiversity (Pineda et al., 2002). In these pastures therophytes are more predominant than perennial species, representing up to $72 \%$ of the species (Azcarate et al., 2002). The screening experiment carried out by Bermejo et al. (2003) to assess the sensitivity of 22 annual species from these ecosystems based on the detection of foliar visible injury indicated that the legumes, especially the assessed Trifolium species, were more sensitive to $\mathrm{O}_{3}$ than grasses. This differential sensitivity might affect the structure and function of these ecosystems and also could modify the nutritive quality of the pastures for the herbivores. Several experiments have also indicated a greater $\mathrm{O}_{3}$ sensitivity of Leguminosae species when compared with Gramineae plants (Nussbaum et al., 1995; Warwick and Taylor, 1995).

Plant sensitivity to this pollutant is usually related to the induction of foliar visible injury. However, the use of foliage health as the main criterion to assess potential $\mathrm{O}_{3}$ adverse effects may not be the best indicator of plant performance due to the weak association between visible injury and other important parameters, such as plant growth, which are more fundamental for plant survival and reproduction (Davison and Barnes, 1998; Reiling and Davison, 1992). Nevertheless, the immense number of wild species makes it essential that species can be ranked and the most sensitive taxa identified for the definition of $\mathrm{O}_{3}$ critical levels (Davison and Barnes, 1998).

To overcome the above-mentioned gaps in knowledge a screening study involving 19 characteristic therophytes of the dehesa acidic grasslands was carried out to falsify the hypothesis that no differences in the growth responses of annual legumes and grasses to ozone exposure should be expected. The following specific objectives of the study were defined: (1) to assess their $\mathrm{O}_{3}$-sensitivity based on plant growth-related parameters, (2) to rank the sensitivity of the selected species and (3) to test whether plant $\mathrm{O}_{3}$ sensitivity can be linked to its classification within a given taxon.

\section{Materials and methods}

\subsection{Plant material}

The 19 species involved in this study are characteristic therophytes of dehesa acidic grasslands of central Iberia peninsula (Montoya et al., 1988; San Miguel 1994). Most of the seeds were collected from a typical dehesa located northwards from Madrid (Dehesa de Moncalvillo, Guadalix de la Sierra, Madrid; $40^{\circ} 40^{\prime} \mathrm{N} 03^{\circ} 46^{\prime} \mathrm{W}$ ). The germoplasm bank of the Agriculture and Environment Council from the Extremadura Autonomous Community supplied the Trifolium striatum, Trifolium subterraneum, Trifolium angustifolium and Ornithopus compressus seeds, collected at different sites from central-western areas of the Iberian peninsula. The Spanish T. subterraneum cv. Zujar was used in the experiments.

All seeds of Leguminosae species were immersed during $24 \mathrm{~h}$ in a Germinator ${ }^{\odot}$ solution (Agro-Orgánicos Mediterráneos S.L., Granada, Spain) to ensure a homogeneous germination. When seeds were swollen they were sown in a $50 \%$ neutral peat and $50 \%$ vermiculite substrate. Gramineae seeds did not experience any pretreatment and they were sown in the same substrate as Leguminosae seeds. The seedlings were transplanted to 2.51 pots with a $50 \%$ peat, $30 \%$ vermiculite and $20 \%$ perlite substrate; $2 \mathrm{~kg} \mathrm{~m}^{-3}$ of a slow-release fertilizer (NPK:15/8/11) was applied. Plants were irrigated with a droplet system to ensure adequate and homogeneous water availability to plant material. The species involved in the study and their sowing dates are presented in Table 1.

\subsection{Ozone treatments}

The assay was performed in an open-top Chamber (OTC) experimental field located at Sant Jaume $\mathrm{d}^{\prime}$ Enveija, Spain $\left(40^{\circ} 41^{\prime} \mathrm{N}, 0^{\circ} 47^{\prime} \mathrm{E}\right)$. The same day the plants were transplanted into pots they were introduced in slightly modified NCLAN-type OTCs (see Gimeno et al., 1999). Three $\mathrm{O}_{3}$ treatments were used: charcoal filtered air (CFA) presenting subphytotoxic $\mathrm{O}_{3}$ levels, non-filtered air (NFA) with close to ambient $\mathrm{O}_{3}$ levels and non-filtered air supplemented with $40 \mathrm{ppb} \mathrm{O}_{3}$ from 07:00 to 17:00 (GMT) 5 days week $^{-1}$ (NFA +). Realistic $\mathrm{O}_{3}$ levels were recorded in the latter treatment, similar to those experienced in the field by the selected species (Palacios et al., 2002; Plaza et al., 1997). Four to six plants from each species were introduced in the chambers and three OTC replicates were used for each $\mathrm{O}_{3}$ treatment. An automatic system was used to provide a continuous monitoring of $\mathrm{O}_{3}$, sulphur dioxide and nitrogen oxides concentrations in the different treatments, along with meteorological parameters such as wind speed and direction, air temperature and relative humidity and photosynthetic active radiation (PAR). A complete description of the chambers and the operation of the system is provided in Alonso et al. (2001).

The $\mathrm{O}_{3}$ exposure index AOT40 currently used by both the UN/ECE CLRTAP ${ }^{1}$ and the European daughter $\mathrm{O}_{3}$ Directive $(2002 / 3 / \mathrm{EC})$ was calculated for each

\footnotetext{
${ }^{1}$ UN/ECE CLRTAP. United Nations/Economic Commission for Europe Convention on Long-Range Transboundary Air Pollution.
} 
Table 1

Time-table and ozone exposure corresponding to the assessment of the ozone sensitivity of dehesa therophytic species

\begin{tabular}{|c|c|c|c|c|c|c|c|}
\hline & \multirow{2}{*}{$\begin{array}{l}\text { Sowing } \\
\text { date }\end{array}$} & \multirow{2}{*}{$\begin{array}{l}\text { Plant } \\
\text { entrance } \\
\text { in OTC }\end{array}$} & \multirow{2}{*}{$\begin{array}{l}\text { First harvest } \\
\text { date } \\
\text { (day/month) }\end{array}$} & \multirow{2}{*}{$\begin{array}{l}\text { Last harvest } \\
\text { date } \\
\text { (day/month) }\end{array}$} & \multirow{2}{*}{$\begin{array}{l}\text { Total } \\
\text { Exposure } \\
\text { length (days) }\end{array}$} & \multicolumn{2}{|c|}{ AOT40 (ppb h) } \\
\hline & & & & & & NFA & $\mathrm{NFA}+$ \\
\hline \multicolumn{8}{|l|}{ Leguminosae (legumes) } \\
\hline Anthyllis cornicina $\mathrm{L}$. & $01 / 08 / 00$ & $07 / 09 / 00$ & $22 / 09$ & $22 / 11$ & 76 & 821 & 15,189 \\
\hline Anthyllis lotoides $\mathrm{L}$. & $01 / 08 / 00$ & $14 / 09 / 00$ & $15 / 09$ & $22 / 11$ & 69 & 415 & 13,144 \\
\hline Biserrula pelecinus $\mathrm{L}$. & $01 / 08 / 00$ & $22 / 09 / 00$ & $22 / 09$ & $28 / 11$ & 67 & 313 & 12,236 \\
\hline Medicago minima (L.) Bartal & $02 / 09 / 00$ & $11 / 10 / 00$ & $09 / 09$ & $23 / 11$ & 43 & 92 & 7222 \\
\hline Ornithopus compressus L. & $02 / 09 / 00$ & $11 / 10 / 00$ & $09 / 10$ & $27 / 11$ & 47 & 313 & 12,099 \\
\hline Trifolium angustifolium $\mathrm{L}$. & $02 / 09 / 00$ & $11 / 10 / 00$ & $09 / 10$ & $23 / 11$ & 43 & 92 & 7222 \\
\hline Trifolium cherleri $\mathrm{L}$. & $01 / 08 / 00$ & $08 / 09 / 00$ & $16 / 09$ & $9 / 11$ & 62 & 783 & 15,493 \\
\hline Trifolitum glomeratum $\mathrm{L}$. & $01 / 08 / 00$ & $08 / 09 / 00$ & $20 / 09$ & $8 / 11$ & 61 & 780 & 13,578 \\
\hline Trifolium striatum $\mathrm{L}$. & $01 / 08 / 00$ & $14 / 09 / 00$ & $15 / 09$ & $7 / 11$ & 54 & 412 & 11,479 \\
\hline Trifolium subterraneum $\mathrm{L}$. & $01 / 08 / 00$ & $08 / 09 / 00$ & $15 / 09$ & $13 / 11$ & 66 & 775 & 12,988 \\
\hline \multicolumn{8}{|l|}{ Gramineae (grasses) } \\
\hline Aegilops geniculata Roth & $01 / 08 / 00$ & $07 / 09 / 00$ & $15 / 09$ & $10 / 11$ & 64 & 818 & 14,183 \\
\hline Aegilops triuncialis $\mathrm{L}$. & $01 / 08 / 00$ & $07 / 09 / 00$ & $16 / 09$ & $11 / 11$ & 65 & 818 & 14,570 \\
\hline Avena sterilis L. & $02 / 09 / 00$ & $03 / 10 / 00$ & $05 / 10$ & $21 / 11$ & 49 & 185 & 8503 \\
\hline Briza maxima $\mathrm{L}$ & $01 / 08 / 00$ & $20 / 09 / 00$ & $21 / 09$ & $22 / 11$ & 63 & 327 & 11,917 \\
\hline Bromus hordeaceus L. & $01 / 08 / 00$ & $07 / 09 / 00$ & $15 / 09$ & $16 / 11$ & 69 & 818 & 13,865 \\
\hline Bromus sterilis L. & $01 / 08 / 00$ & $14 / 09 / 00$ & $15 / 09$ & $20 / 11$ & 67 & 415 & 12,550 \\
\hline Cynosurus echinatus L. & $01 / 08 / 00$ & $14 / 09 / 00$ & $15 / 09$ & $21 / 11$ & 68 & 415 & 12,791 \\
\hline Lolium rigidum Gaudin & $02 / 09 / 00$ & $11 / 10 / 00$ & $09 / 10$ & $23 / 11$ & 43 & 92 & 7222 \\
\hline Vulpia myuros (L.) C.C.Gmelin & $01 / 08 / 00$ & $20 / 09 / 00$ & $21 / 09$ & $22 / 11$ & 63 & 327 & 11,917 \\
\hline
\end{tabular}

species and $\mathrm{O}_{3}$ treatment as the sum of the differences between $\mathrm{O}_{3}$ hourly concentrations in $\mathrm{ppb}$ and $40 \mathrm{ppb}$ for each hour when the concentration exceeds $40 \mathrm{ppb}$ and solar radiation is above $50 \mathrm{~W} \mathrm{~m}^{-2}$.

\subsection{Growth-related parameters}

Plant height, diameter, aerial and root biomass of plant material were determined when plants were exposed to the different $\mathrm{O}_{3}$ treatments during 43-77 days, mostly depending on the timing of seed germination.

Plant height and diameter were used to estimate the canopy volume and surface of the plant species involved in the experiment. Two diameter estimations were carried out per plant, their mean value was used for subsequent statistical analyses. The aboveground biomass was harvested by excising the plants at the surface of the substrate. Leaves and stems of Leguminosae plants were separated and dried at $60{ }^{\circ} \mathrm{C}$ until constant weight and subsequently weighed to determine their foliage/stem dry weight ratio. A similar procedure was followed for Gramineae species. Similarly, roots were cautiously extracted, washed, dried at $60{ }^{\circ} \mathrm{C}$ and weighed afterwards. The shoot/root ratios were also calculated to evaluate potential shifts in photosynthate distribution. Prior to the entrance of plant material in the OTCs the mean of the initial weights of the root and shoot biomass of an extra-set of 10 plants per species was used to derive the relative growth rates (RGR, g week $^{-1}$ ) of the experimental plants. The RGRs for aerial, root, and total biomass were calculated using the formula:

$\mathrm{RGR}=\ln W_{2} \ln W_{1} / t_{2} t_{1}$

where $W_{2}$ and $W_{1}$ are the dry weights at the final harvest and at the harvest performed prior to the entrance of plant material in the chamber, respectively, and $t_{2}$ and $t_{1}$ are the number of days of both harvests (Hunt, 1990). Details of the dates when the plants were introduced in the chambers and the length of $\mathrm{O}_{3}$ exposure in the different treatments can be found in Table 1 .

\subsection{Statistical analyses}

An ANOVA analysis for each parameter and species was performed to evaluate $\mathrm{O}_{3}$ effects on plant growthrelated parameters. Also, a combined analysis involving all the assessed species was performed to assess whether plant sensitivity to $\mathrm{O}_{3}$ exposure could be related to plant family; therefore a two-way ANOVA analyses were carried out considering ozone exposure and family as factors. When significant differences $(p<0.05)$ were detected, the differences between means were assessed using the least significant difference (LSD) test. Normal probability plots and scatter plots of residuals were used to test data normality. Levenne tests (Milliken and Johnson, 1994) were applied to check the variance homocedasticity. When necessary logarithmic or square-root transformations were used. The relationship 
between growth parameters and the different $\mathrm{O}_{3}$ exposure indices was analysed using Pearson's correlation index and the level of significance was determined using the student $t$-test. All statistical analyses were carried out using Statistica 97 software.

\section{Results and discussion}

Of the 19 species assessed in this study, only Anthilllis cornicina could be considered as resistant to $\mathrm{O}_{3}$ exposure since it was not significantly affected by any of the assessed parameters on this species. The growth or the foliar morphology of the remaining species was adversely affected by those concentrations of the pollutant which are actually recorded in the dehesas of the central Iberian peninsula (Palacios et al., 2002; Plaza et al., 1997). However, the nature of the effect differed depending on species and family.

In general, the Leguminosae species were more sensitive to $\mathrm{O}_{3}$ than Gramineae species regarding the response of the assessed growth-related parameters as shown in Tables $2-4$. Ozone exposure induced significant detrimental effects on the aerial and root RGRs of $70 \%$

Table 2

Plant growth-related parameters of the legume grown in the different $\mathrm{O}_{3}$ treatments

\begin{tabular}{|c|c|c|c|c|c|c|c|}
\hline & Foliage dw (g) & Stem dw $(\mathrm{g})$ & Root RGR & Aerial RGR & Total RGR & Foliage/stem & Shoot/root \\
\hline \multicolumn{8}{|c|}{ Anthyllis cornicina $\mathrm{L}$. } \\
\hline CFA & 1.91 & 0.26 & 0.26 & 0.40 & 0.38 & 8.88 & 10.27 \\
\hline NFA & 1.82 & 0.26 & 0.28 & 0.39 & 0.37 & 6.93 & 7.17 \\
\hline NFA + & 2.44 & 0.50 & 0.25 & 0.43 & 0.40 & 5.50 & 12.02 \\
\hline \multicolumn{8}{|c|}{ Anthyllis lotoides L. } \\
\hline $\mathrm{CFA}$ & 9.07 & 2.32 & - & 0.54 & - & 4.25 & - \\
\hline NFA & 9.52 & 2.25 & - & 0.55 & - & 4.43 & - \\
\hline $\mathrm{NFA}+$ & 8.42 & 2.01 & - & 0.54 & - & 5.07 & - \\
\hline \multicolumn{8}{|c|}{ Biserrula pelecinus $\mathrm{L}$. } \\
\hline $\mathrm{CFA}$ & $9.15^{\mathrm{a}}$ & 4.53 & 0.34 & $0.36^{\mathrm{b}}$ & $0.36^{\mathrm{a}}$ & 2.07 & 4.76 \\
\hline NFA & $7.00^{\mathrm{ab}}$ & 3.76 & 0.33 & $0.34^{\mathrm{ab}}$ & $0.34^{\mathrm{ab}}$ & 1.86 & 3.20 \\
\hline $\mathrm{NFA}+$ & $5.16^{\mathrm{b}}$ & 2.39 & 0.31 & $0.29^{\mathrm{a}}$ & $0.29^{\mathrm{b}}$ & 2.13 & 2.66 \\
\hline \multicolumn{8}{|c|}{ Medicago minima (L.) Bartal } \\
\hline $\mathrm{CFA}$ & $0.95^{\mathrm{a}}$ & $0.47^{\mathrm{a}}$ & $0.41^{\mathrm{a}}$ & $0.46^{\mathrm{b}}$ & $0.44^{\mathrm{a}}$ & $2.07^{\mathrm{a}}$ & 2.27 \\
\hline NFA & $0.56^{\mathrm{b}}$ & $0.30^{\mathrm{b}}$ & $0.39^{\mathrm{a}}$ & $0.44^{\mathrm{b}}$ & $0.42^{\mathrm{a}}$ & $1.87^{\mathrm{ab}}$ & 2.41 \\
\hline $\mathrm{NFA}+$ & $0.45^{\mathrm{b}}$ & $0.27^{\mathrm{b}}$ & $0.32^{\mathrm{b}}$ & $0.37^{\mathrm{a}}$ & $0.35^{\mathrm{b}}$ & $1.64^{\mathrm{b}}$ & 2.33 \\
\hline \multicolumn{8}{|c|}{ Ornithopus compressus $\mathrm{L}$. } \\
\hline $\mathrm{CFA}$ & 3.07 & 0.52 & 0.51 & $0.75^{\mathrm{a}}$ & 0.65 & 5.99 & $3.06^{\mathrm{a}}$ \\
\hline NFA & 2.52 & 0.39 & 0.50 & 0.72 & 0.61 & 6.58 & $2.72^{\mathrm{a}}$ \\
\hline NFAA + & 2.44 & 0.38 & 0.52 & 0.72 & 0.62 & 6.61 & $2.18^{\mathrm{b}}$ \\
\hline \multicolumn{8}{|c|}{ Trifolium angustifolium $\mathrm{L}$. } \\
\hline CFA & $1.43^{\mathrm{a}}$ & $0.17^{\mathrm{a}}$ & $0.54^{\mathrm{a}}$ & $0.59^{\mathrm{b}}$ & $0.56^{\mathrm{a}}$ & 8.98 & 1.86 \\
\hline NFA & $1.32^{\mathrm{a}}$ & $0.15^{\mathrm{a}}$ & $0.53^{\mathrm{a}}$ & $0.57^{\mathrm{b}}$ & $0.56^{\mathrm{a}}$ & 9.23 & 1.73 \\
\hline NFA+ & $0.88^{\mathrm{b}}$ & $0.10^{\mathrm{b}}$ & $0.46^{\mathrm{b}}$ & $0.51^{\mathrm{a}}$ & $0.49^{\mathrm{b}}$ & 10.57 & 1.89 \\
\hline \multicolumn{8}{|c|}{ Trifolium cherleri $\mathrm{L}$. } \\
\hline CFA & $6.16^{\mathrm{a}}$ & 0.87 & $0.36^{\mathrm{a}}$ & $0.51^{\mathrm{b}}$ & $0.48^{\mathrm{a}}$ & 5.88 & $7.66^{\mathrm{a}}$ \\
\hline NFA & $3.19^{\mathrm{ab}}$ & 1.03 & $0.36^{\mathrm{a}}$ & $0.46^{\mathrm{ab}}$ & $0.43^{\mathrm{ab}}$ & 3.22 & $4.93^{\mathrm{b}}$ \\
\hline $\mathrm{NFA}+$ & $2.30^{\mathrm{b}}$ & 0.70 & $0.31^{\mathrm{b}}$ & $0.42^{\mathrm{a}}$ & $0.39^{\mathrm{b}}$ & 3.66 & $5.35^{\mathrm{b}}$ \\
\hline \multicolumn{8}{|c|}{ Trifolium glomeratum $\mathrm{L}$. } \\
\hline CFA & $10.66^{\mathrm{a}}$ & 1.99 & $0.50^{\mathrm{a}}$ & $0.66^{\mathrm{b}}$ & $0.63^{\mathrm{a}}$ & 5.63 & $6.72^{\mathrm{a}}$ \\
\hline NFA & $10.68^{\mathrm{a}}$ & 2.01 & $0.49^{\mathrm{a}}$ & $0.65^{\mathrm{ab}}$ & $0.62^{\mathrm{ab}}$ & 5.56 & $6.66^{\mathrm{a}}$ \\
\hline $\mathrm{NFA}+$ & $8.65^{\mathrm{b}}$ & 1.35 & $0.41^{\mathrm{b}}$ & $0.62^{\mathrm{a}}$ & $0.57^{\mathrm{b}}$ & 7.53 & $9.97^{\mathrm{b}}$ \\
\hline \multicolumn{8}{|c|}{ Trifolium striatum L. } \\
\hline CFA & $6.87^{\mathrm{a}}$ & $1.85^{\mathrm{a}}$ & $0.65^{\mathrm{a}}$ & $0.71^{\mathrm{b}}$ & $0.69^{\mathrm{a}}$ & 3.75 & $3.42^{\mathrm{a}}$ \\
\hline NFA & $4.92^{\mathrm{b}}$ & $1.39^{\mathrm{ab}}$ & $0.60^{\mathrm{b}}$ & $0.67^{\mathrm{b}}$ & $0.66^{\mathrm{a}}$ & 3.71 & $4.11^{\mathrm{ab}}$ \\
\hline $\mathrm{NFA}+$ & $3.36^{\mathrm{b}}$ & $0.95^{\mathrm{b}}$ & $0.49^{\mathrm{c}}$ & $0.57^{\mathrm{a}}$ & $0.55^{\mathrm{b}}$ & 3.63 & $4.55^{\mathrm{b}}$ \\
\hline \multicolumn{8}{|c|}{ Trifolium subterraneum $\mathrm{L}$. } \\
\hline CFA & 13.79 & $2.70^{\mathrm{a}}$ & $0.27^{\mathrm{a}}$ & $0.37^{\mathrm{b}}$ & $0.35^{\mathrm{a}}$ & 5.20 & $6.68^{\mathrm{a}}$ \\
\hline NFA & 13.17 & $1.83^{\mathrm{b}}$ & $0.23^{\mathrm{b}}$ & $0.39^{\mathrm{b}}$ & $0.36^{\mathrm{a}}$ & 7.53 & $9.28^{\mathrm{ab}}$ \\
\hline $\mathrm{NFA}+$ & 9.98 & $1.34^{\mathrm{b}}$ & $0.17^{\mathrm{c}}$ & $0.34^{\mathrm{a}}$ & $0.29^{\mathrm{b}}$ & 7.58 & $10.75^{\mathrm{b}}$ \\
\hline
\end{tabular}

Different letters indicate significant effects between $\mathrm{O}_{3}$ treatments $(p<0.05)$. CFA, charcoal filtered air; NFA, non-filtered air, NFA + , non-filtered air supplemented with $40 \mathrm{ppb}$ of $\mathrm{O}_{3}$. 
Table 3

Plant growth-related parameters of the grasses grown in the different $\mathrm{O}_{3}$ treatments

\begin{tabular}{|c|c|c|c|c|}
\hline & Root RGR & Aerial RGR & Total RGR & Shoot/root \\
\hline \multicolumn{5}{|c|}{ Aegilops geniculata Roth } \\
\hline CFA & $0.35^{\mathrm{a}}$ & 0.35 & 0.36 & 1.53 \\
\hline NFA & $0.34^{\mathrm{a}}$ & 0.34 & 0.33 & 1.19 \\
\hline $\mathrm{NFA}+$ & $0.27^{b}$ & 0.31 & 0.29 & 1.72 \\
\hline \multicolumn{5}{|c|}{ Aegilops triuncialis L. } \\
\hline CFA & 0.37 & 0.41 & 0.38 & 1.59 \\
\hline NFA & 0.39 & 0.42 & 0.40 & 1.66 \\
\hline $\mathrm{NFA}+$ & 0.37 & 0.42 & 0.39 & 1.90 \\
\hline \multicolumn{5}{|c|}{ Avena sterilis L. } \\
\hline CFA & 0.61 & 0.57 & 0.59 & 0.25 \\
\hline NFA & 0.61 & 0.57 & 0.59 & 0.22 \\
\hline $\mathrm{NFA}+$ & 0.59 & 0.55 & 0.58 & 0.41 \\
\hline \multicolumn{5}{|c|}{ Briza maxima L. } \\
\hline CFA & 0.61 & 0.59 & 0.60 & 2.49 \\
\hline NFA & 0.66 & 0.60 & 0.63 & 1.85 \\
\hline $\mathrm{NFA}+$ & 0.61 & 0.57 & 0.59 & 2.71 \\
\hline \multicolumn{5}{|c|}{ Bromus hordeaceus L. } \\
\hline CFA & 0.60 & 0.48 & 0.53 & 0.63 \\
\hline NFA & 0.58 & 0.49 & 0.54 & 0.64 \\
\hline $\mathrm{NFA}+$ & 0.52 & 0.48 & 0.50 & 1.06 \\
\hline \multicolumn{5}{|c|}{ Bromus sterilis L. } \\
\hline CFA & - & 0.53 & - & - \\
\hline NFA & - & 0.52 & - & - \\
\hline $\mathrm{NFA}+$ & - & 0.51 & - & - \\
\hline \multicolumn{5}{|c|}{ Lolium rigidum Gaudin } \\
\hline CFA & 0.83 & 0.72 & 0.75 & 1.56 \\
\hline NFA & 0.83 & 0.69 & 0.73 & 1.33 \\
\hline $\mathrm{NFA}+$ & 0.81 & 0.68 & 0.72 & 1.51 \\
\hline \multicolumn{5}{|c|}{ Cynosumus echinatus L. } \\
\hline CFA & $0.62^{\mathrm{a}}$ & 0.73 & $0.69^{\mathrm{a}}$ & $2.98^{\mathrm{a}}$ \\
\hline NFA & $0.70^{\mathrm{b}}$ & 0.74 & $0.73^{\mathrm{b}}$ & $1.12^{\mathrm{b}}$ \\
\hline $\mathrm{NFA}+$ & $0.65^{\mathrm{ab}}$ & 0.74 & $0.70^{\mathrm{a}}$ & $2.26^{\mathrm{a}}$ \\
\hline \multicolumn{5}{|c|}{ Vulpia myuros (L.) C. C. Gmelin } \\
\hline CFA & - & 0.55 & - & - \\
\hline NFA & - & 0.52 & - & - \\
\hline $\mathrm{NFA}+$ & - & 0.55 & - & - \\
\hline
\end{tabular}

Different letters indicate significant effects between $\mathrm{O}_{3}$ treatments $(p<0.05)$. CFA, charcoal filtered air; NFA, non-filtered air, NFA+, non-filtered air supplemented with $40 \mathrm{ppb}$ of $\mathrm{O}_{3}$.

and $67 \%$, respectively, of the assessed Leguminosae species and caused a reduction in the total RGR of $78 \%$ of the species of this family. The root RGR was only affected in $29 \%$ of the Gramineae species involved in the experiment, while no detrimental effects were found on their aerial biomass RGR and a single species of this family showed a significant effect on its total RGR.

A combined analysis using a two-way ANOVA was carried out to assess whether total RGR was affected by ozone exposure and/or plant family (see Fig. 1). Ozone significantly $(p<0.05)$ affected RGRs, inducing lower rates in the $\mathrm{NFA}+$ treatment when compared to CFA or NFA plants. Similarly, grass species significantly $(p<0.0001)$ presented greater RGRs than legumes while a trend $(p=0.07)$ towards a family- $\mathrm{O}_{3}$ interaction was found. Grasses and legumes presented similar RGRs in the CFA treatment while the total RGR of grasses was greater than for legumes when both taxa were exposed to the NFA or NFA + treatments. This pattern of sensitivity for both plant families based on growth responses to $\mathrm{O}_{3}$ is in agreement with that found when foliar visible injury was considered (Bermejo et al., 2003), although in this experiment a significant $\mathrm{O}_{3}-$ family interaction was detected. These results match with other studies reporting a greater sensitivity of the Leguminosae family when compared with Gramineae species (Bungener et al., 1999; Warwick and Taylor, 1995). Therefore a separate analysis of the results was carried out for both families.

\subsection{Ozone effects on species of the Leguminosae family}

Ambient $\mathrm{O}_{3}$ levels (NF treatment) corresponding to AOT40 values ranging 92-775 ppb h (Table 1) caused significant reductions in the aerial biomass (foliage or stem biomass) of $T$. striatum, $T$. subterraneum and Medicago minima (Table 2). Ozone affected both the foliage and the stem of Medicago, that showed reductions of 41 and $36 \%$, respectively, when compared with the control treatment. A similar pattern was found in $T$. striatum, however, ambient $\mathrm{O}_{3}$ levels only significantly affected its foliage dry weight (by $28 \%$ ), while shoot biomass was the most affected parameter in $T$. subterraneum $(32 \%)$. Ambient $\mathrm{O}_{3}$ exposure also induced adverse effects on root RGR of $T$. striatum and $T$. subterraneum, with reductions ranging $8-15 \%$ when compared with control plants.

Above ambient $\mathrm{O}_{3}$ levels $(\mathrm{NF}+$ treatment) corresponding to AOT40 values ranging $7222-15,493 \mathrm{ppb} \mathrm{h}$ (Table 1) induced detrimental effects in the range of 6-14\% in the aerial RGR of $T$. angustifolium, Trifolium glomeratum and T. subterraneum and of ca. $20 \%$ in Biserrula pelecinus, $M$. minima, Trifolium cherleri and $T$. striatum. These $\mathrm{O}_{3}$ levels determined reductions $(147-37 \%)$ in the root RGR of these species except for Biserrula, where no effects were detected. The total RGR was adversely affected in these seven species following their exposure to the NFA+ treatment, reductions in the $10-21 \%$ range were found when compared with control plants, Medicago and $T$. striatum being the most affected species. The intensity of the $\mathrm{O}_{3}$-induced adverse effects are in the range of those reported by Warwick and Taylor (1995) regarding the sensitivity of calcareous herbaceous species, where the most sensitive species showed $20 \%$ depletions in its root and shoot RGRs. However, in our study the greatest adverse effect was found in the root RGR of T. subterraneum $(37 \%)$. Ozone exposure did not determine any effect on the root, aerial or total RGR of Anthyllis cornicina, Anthyllis lotoides and O. compressus. 
Table 4

Ozone-induced effects on plant canopy-related parameters of the dehesa therophytes involved in the experiment

\begin{tabular}{|c|c|c|c|c|c|c|c|c|}
\hline \multirow[t]{2}{*}{ Exposure } & \multicolumn{4}{|l|}{ Leguminosae } & \multicolumn{4}{|l|}{ Gramineae } \\
\hline & Diameter $(\mathrm{cm})$ & Height $(\mathrm{cm})$ & Surface $\left(\mathrm{m}^{2}\right)$ & Vol. $\left(\mathrm{dm}^{3}\right)$ & Diameter $(\mathrm{cm})$ & Height $(\mathrm{cm})$ & Surface $\left(\mathrm{m}^{2}\right)$ & Vol. $\left(\mathrm{dm}^{3}\right)$ \\
\hline & \multicolumn{4}{|c|}{ Anthyllis cornicina L. } & \multicolumn{4}{|c|}{ Aegilops geniculata Roth } \\
\hline CFA & 26.66 & 7.16 & 0.072 & 5.32 & 46.53 & $14.18^{\mathrm{a}}$ & 0.22 & 31 \\
\hline NFA & 26.08 & 7.50 & 0.069 & 5.40 & 46.46 & $15.92^{\mathrm{a}}$ & 0.22 & 35 \\
\hline \multirow[t]{2}{*}{ NFA +} & 23.91 & 7.17 & 0.058 & 4.13 & 47.78 & $12.00^{\mathrm{b}}$ & 0.23 & 29 \\
\hline & \multicolumn{4}{|c|}{ Anthyllis lotoides $\mathrm{L}$. } & \multicolumn{4}{|c|}{ Aegilops triuncialis } \\
\hline CFA & 48.88 & $8.44^{\mathrm{a}}$ & 0.24 & 21.26 & 57.03 & 14.43 & 0.33 & 48 \\
\hline NFA & 49.5 & $8.77^{\mathrm{a}}$ & 0.25 & 22.77 & 59.08 & 14.16 & 0.37 & 51 \\
\hline $\mathrm{NFA}+$ & 45.33 & $7.33^{\mathrm{b}}$ & 0.23 & 16.49 & 57.96 & 14.07 & 0.35 & 48 \\
\hline $\begin{array}{l}\mathrm{CFA} \\
\mathrm{NFA} \\
\mathrm{NFA}+\end{array}$ & $\begin{array}{l}\text { Biserrula peleci } \\
62.3^{\mathrm{a}} \\
59.2^{\mathrm{a}} \\
40.4^{\mathrm{b}}\end{array}$ & $\begin{array}{l}\mathrm{L} . \\
6.6 \\
- \\
6.2\end{array}$ & $\begin{array}{l}0.39^{\mathrm{a}} \\
0.37^{\mathrm{a}} \\
0.17^{\mathrm{b}}\end{array}$ & $\begin{array}{l}25.72^{\mathrm{a}} \\
- \\
10.63^{\mathrm{b}}\end{array}$ & $\begin{array}{l}\text { Avena sterilis } \mathrm{L} \\
103.29^{\mathrm{a}} \\
100.54^{\mathrm{a}} \\
87.16^{\mathrm{b}}\end{array}$ & $\begin{array}{l}18.91 \\
17.5 \\
16.92\end{array}$ & $\begin{array}{l}1.08 \\
1.02 \\
0.77\end{array}$ & $\begin{array}{l}199^{\mathrm{a}} \\
174^{\mathrm{a}} \\
128^{\mathrm{b}}\end{array}$ \\
\hline $\begin{array}{l}\mathrm{CFA} \\
\mathrm{NFA} \\
\mathrm{NFA}+\end{array}$ & $\begin{array}{l}\text { Medicago minir } \\
19.04^{\mathrm{a}} \\
17.66^{\mathrm{ab}} \\
16.25^{\mathrm{b}}\end{array}$ & $\begin{array}{l}\text { (L.) Bartal } \\
4.41^{\mathrm{a}} \\
3.91^{\mathrm{ab}} \\
3.33^{\mathrm{b}}\end{array}$ & $\begin{array}{l}0.037^{\mathrm{a}} \\
0.032 \\
0.027^{\mathrm{b}}\end{array}$ & $\begin{array}{l}1.66^{\mathrm{a}} \\
1.31^{\mathrm{ab}} \\
0.91^{\mathrm{b}}\end{array}$ & $\begin{array}{l}\text { Briza maxima } \\
55.13 \\
56.83 \\
49.29\end{array}$ & $\begin{array}{l}19.81 \\
20.08 \\
18.00\end{array}$ & $\begin{array}{l}0.31 \\
0.33 \\
0.25\end{array}$ & $\begin{array}{l}61^{\mathrm{a}} \\
68^{\mathrm{a}} \\
45^{\mathrm{b}}\end{array}$ \\
\hline $\mathrm{NFA}+$ & \multicolumn{4}{|c|}{ Ornithopus compressus L. } & \multicolumn{4}{|c|}{ Bromus hordeaceus L. } \\
\hline CFA & $38.44^{\mathrm{a}}$ & 8.00 & $0.15^{\mathrm{a}}$ & 12.07 & 67.95 & $34.08^{\mathrm{a}}$ & 0.46 & 161 \\
\hline NFA & $32.92^{\mathrm{b}}$ & 8.28 & $0.11^{\mathrm{b}}$ & 9.17 & 66.87 & $28.25^{\mathrm{b}}$ & 0.46 & 132 \\
\hline \multirow[t]{2}{*}{$\mathrm{NFA}+$} & $35.00^{\mathrm{b}}$ & 8.41 & $0.12^{\mathrm{b}}$ & 11.04 & 64.16 & $28.00^{\mathrm{b}}$ & 0.42 & 119 \\
\hline & \multicolumn{4}{|c|}{ Trifolium angustifolium $\mathrm{L}$. } & \multicolumn{4}{|c|}{ Bromus sterilis L. } \\
\hline CFA & $28.09^{\mathrm{b}}$ & 12.18 & $0.079^{\mathrm{a}}$ & $9.71^{\mathrm{a}}$ & 61.83 & $24.44^{\mathrm{a}}$ & 0.38 & 94 \\
\hline NFA & $25.62^{\mathrm{b}}$ & 11.83 & $0.066^{\mathrm{b}}$ & $7.94^{\mathrm{a}}$ & 63.36 & $22.42^{\mathrm{b}}$ & 0.40 & 89 \\
\hline \multirow[t]{2}{*}{$\mathrm{NFA}+$} & $22.20^{\mathrm{a}}$ & 10.58 & $0.049^{\mathrm{c}}$ & $5.52 \mathrm{~b}$ & 64.33 & $23.00^{\mathrm{b}}$ & 0.42 & 96 \\
\hline & \multicolumn{4}{|c|}{ Trifolium cherleri $\mathrm{L}$. } & \multicolumn{4}{|c|}{ Lolium rigidum Gaudin } \\
\hline CFA & 20.46 & 8.33 & 0.046 & 3.44 & 65.66 & 19.88 & 0.44 & 87 \\
\hline NFA & 19.53 & 6.50 & 0.040 & 2.69 & 68.05 & 20.66 & 0.47 & 98 \\
\hline \multirow[t]{2}{*}{$\mathrm{NFA}+$} & 18.54 & 7.33 & 0.036 & 2.37 & 71.25 & 20.13 & 0.52 & 106 \\
\hline & \multicolumn{4}{|c|}{ Trifolium glomeratum L. } & \multicolumn{4}{|c|}{ Cynosurus echinatus $\mathrm{L}$. } \\
\hline CFA & 30.60 & $7.38^{\mathrm{a}}$ & 0.13 & 9.76 & $49.5^{\mathrm{a}}$ & $25.55^{\mathrm{a}}$ & 0.24 & $62^{\mathrm{a}}$ \\
\hline NFA & 34.71 & $6.07^{\mathrm{b}}$ & 0.12 & 7.57 & $50.38^{\mathrm{a}}$ & $22.66^{\mathrm{b}}$ & 0.27 & $61^{\mathrm{ab}}$ \\
\hline \multirow[t]{2}{*}{ NFA+ } & 28.80 & $5.69^{\mathrm{b}}$ & 0.11 & 7.08 & $46.56^{\mathrm{b}}$ & $23.44^{\mathrm{b}}$ & 0.22 & $51^{\mathrm{b}}$ \\
\hline & Trifolium striat & & & & Vulpia myuros & C. C. Gmelin & & \\
\hline CFA & 30.10 & $12.90^{\mathrm{a}}$ & $0.090^{\mathrm{a}}$ & $11.72^{\mathrm{a}}$ & $60.58^{\mathrm{a}}$ & $27.5^{\mathrm{a}}$ & 0.37 & $102^{\mathrm{a}}$ \\
\hline NFA & 26.30 & $11.10^{\mathrm{b}}$ & $0.069^{\mathrm{b}}$ & $7.80^{\mathrm{b}}$ & $54.77^{\mathrm{b}}$ & $22.72^{\mathrm{b}}$ & 0.30 & $71^{\mathrm{b}}$ \\
\hline NFA + & 22.13 & $9.92^{\mathrm{b}}$ & $0.050^{\mathrm{c}}$ & $5.22^{\mathrm{c}}$ & 57.25 & $24.70^{\mathrm{ab}}$ & 0.33 & $81^{a b}$ \\
\hline & Trifolium subte & neum $\mathrm{L}$. & & & & & & \\
\hline CFA & $38.12^{\mathrm{a}}$ & $14.00^{\mathrm{a}}$ & $0.150^{\mathrm{a}}$ & $22.10^{\mathrm{a}}$ & & & & \\
\hline $\mathrm{NFA}$ & $31.08^{\mathrm{b}}$ & $10.66^{\mathrm{b}}$ & $0.100^{\mathrm{a}}$ & $11.50^{\mathrm{b}}$ & & & & \\
\hline NFA + & $29.41^{\mathrm{b}}$ & $11.08^{\mathrm{b}}$ & $0.088^{\mathrm{b}}$ & $10.13^{b}$ & & & & \\
\hline
\end{tabular}

Different letters indicate significant effects between $\mathrm{O}_{3}$ treatments $(p<0.05)$. CFA, charcoal filtered air; NFA, non-filtered air, NFA+, non-filtered air supplemented with $40 \mathrm{ppb}$ of $\mathrm{O}_{3}$.

Ozone exposure determined shifts in the shoot/root dry weight biomass ratio of $55 \%$ of the legumes involved in the experiment. Ambient (AOT40 = $783 \mathrm{ppb}$ h) and above ambient $\mathrm{O}_{3}$ levels (AOT40 $=15,493 \mathrm{ppb}$ h) induced average reductions of $33 \%$ in the shoot/root ratio of $T$. cherleri, when compared to CFA plants. Similarly, the $O$. compressus plants grown in the NFA+ chambers presented a $29 \%$ lower shoot/root ratio than CFA plants, in association with AOT40 values of $12,099 \mathrm{ppb} \mathrm{h}$. On the contrary, increases in the shoot/ root ratio, influenced by a greater $\mathrm{O}_{3}$ adverse effect on the root systems, were found in the NFA+ plants (AOT40 values over $11400 \mathrm{ppb}$ h) of $T$. subterraneum, $T$. striatum and $T$. glomeratum (33-60\%) when compared with those grown in the CFA treatment. The largest $\mathrm{O}_{3}$ induced increase in the shoot/root ratio was found in T. subterraneum $(38 \%)$. The alteration of carbon allocation is a common effect induced by $\mathrm{O}_{3}$ (Cooley and Manning, 1987) and has also been reported in similar experiments involving the exposure of herbaceous 


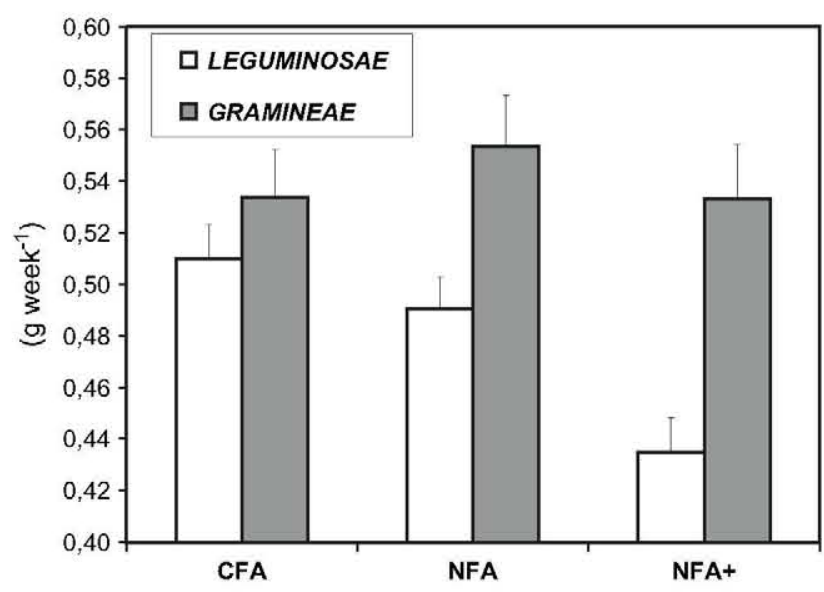

Fig. 1. Average total relative growth rate for Leguminosae $(O)$ and Gramineae (-) plants grown in the different $\mathrm{O}_{3}$ treatments. $\mathrm{CFA}=$ charcoal filtered air; $\mathrm{NFA}=$ non-filtered air; $\mathrm{NFA}+=$ non-filtered air supplemented with $40 \mathrm{ppb} \mathrm{O}_{3}$. Mean $\pm \mathrm{SE}$.

species. However, shoot or root partitioning was speciesdependent (Franzaring et al., 2000; Reiling and Davison, 1992; Warwick and Taylor, 1995).

The observed changes in shoot/root dry weight biomass ratio or in the root RGR might determine important ecological implications in the dehesa Mediterranean systems that usually experience water and nutrient limitations. A significant amount of the photosynthates of these species is usually accumulated in the root system to overcome stressful periods when soil moisture and nutrient availability are limited. Therefore the observed shifts induced by $\mathrm{O}_{3}$ on shoot/root ratio may affect the competitive ability of these species (Aers et al., 1991; Franzaring et al., 2000).

Changes in plant morphology were observed in all the species following their exposure to $\mathrm{O}_{3}$ except for $A$. cornicina and $T$. cherleri (see Table 4). These effects did not necessarily correspond with the observed responses in aerial or subterranean biomass or RGR, as was the case for $O$. compressus.

A ranking of decreasing $\mathrm{O}_{3}$ sensitivity is proposed for the Leguminosae species involved in the experiment, based on the changes induced by ambient and above ambient levels of this pollutant on the aerial, root and total RGRs and the shoot/root ratio. The responses of the morphological parameters were used to fine-tune the $\mathrm{O}_{3}$ sensitivity of the different species. The first criterion was to select those species showing adverse effects on their RGRs following their exposure to ambient $\mathrm{O}_{3}$ levels ( $T$. striatum, $T$. subterraneum). The second criterion was to choose those species where above ambient $\mathrm{O}_{3}$ levels induced detrimental effects on their RGRs and were simultaneously affected by ambient levels on morphological parameters ( $T$. cherleri, $T$. angustifolium). A third sensitivity group was defined by those species that only showed adverse effects when exposed to the $\mathrm{NF}+$ treatment $(M$. minima,
T. glomeratum, Biserrula). The group encompassing the least sensitive species was defined by the lack of response of their RGR even when exposed to the maximum $\mathrm{O}_{3}$ levels or just showing adverse effects on a single morphological parameter (the two Anthyllis species). $O$. compressus was considered slightly more sensitive than this group since $\mathrm{O}_{3}$ exposure altered its shoot/root ratio. As a result the following ranking is proposed:

T. striatum, $T$. subterraneum $>T$. cherleri,

$T$. angustifolium $>M$. minima, $T$. glomeratum,

B. pelecinus $>O$. compressus $>A$. cornicina, A. lotoides.

This sensitivity ranking based on growth-related parameters showed a great similarity with that based on the induction of foliar injury reported by Bermejo et al. (2003). However, $T$. glomeratum was more resistant than expected from visible injury responses while the opposite was true for $M$. minima. These types of disagreements in the sensitivity classifications when visible injury or growth-related parameters have been reported by many authors in the literature (see review by Davison and Barnes, 1998). It is worth noting the high sensitivity of the Trifolium species involved in the study, in agreement with Nebel and Fuhrer (1994), Nussbaum et al. (1995), Karlsson et al. (1995), Balls et al. (1996), Ashmore et al. (1996), Bergmann et al. (1999) and Gimeno et al. (2004). Since the ecology of these Trifolium species is quite different, Bergmann et al. (1999) suggested that their great sensitivity could be related to evolutionary and genetic features.

\subsection{Ozone effects on species of the Gramineae family}

Significant $\mathrm{O}_{3}$ effects on the aerial, root or total RGRs were found in only two of the Gramineae species involved in the experiment (see Table 3 ). Above ambient $\mathrm{O}_{3}$ levels $($ AOT40 $=14,183 \mathrm{ppbh})$ caused a $23 \%$ reduction in the root RGR of Aegilops geniculata. Ambient $\mathrm{O}_{3}$ levels $(\mathrm{AOT} 40=415 \mathrm{ppb}$ ) induced a $13 \%$ increase in this parameter on Cynosurus echinatus when compared with CFA plants. The aerial RGR was not affected on any of the assessed grass species. Ambient $\mathrm{O}_{3}$ $(415 \mathrm{ppbh})$ levels induced a $6 \%$ increase in the total biomass RGR of Cynosurus echinatus; no effects on this parameter were found for the remaining grass species.

Regarding $\mathrm{O}_{3}$ effects on plant structure and canopy architecture (see Tables 3 and 4), ambient $\mathrm{O}_{3}$ levels determined a reduction in the shoot/root ratio of C. echinatus. No effects on this parameter were found in any of the remaining species. Ambient $\mathrm{O}_{3}$ levels with AOT40 values ranging from $327-818 \mathrm{ppbh}$ induced $87-17 \%$ reductions in the height of Bromus hordeaceus, B. sterilis, C. echinatus and Vulpia myuros. Above ambient $\mathrm{O}_{3}$ levels (AOT40 levels in the 12,500$14,200 \mathrm{ppb}$ h range) determined $6-18 \%$ reductions in 
the height of $A$. geniculata, $B$. hordeaceus, B. sterilis and C. echinatus. No effects on plant surface were detected in any grass species when exposed to the NFA or NFA+ treatment. A $21 \%$ reduction was induced by ambient $\mathrm{O}_{3}$ exposure $($ AOT $40=327 \mathrm{ppbh}$ ) in the plant canopy volume of $V$. myuros plants, when compared to CFAtreated plants. Above ambient $\mathrm{O}_{3}$ levels corresponding to AOT40 values in the $8500-12,800 \mathrm{ppb}$ h range were associated with reductions of 36,26 and $18 \%$ in the plant volume of A. sterilis, B. maxima and C. echinatus, respectively.

Although the grass species involved in the experiment were rather insensitive to $\mathrm{O}_{3}$, they were ranked according to the AOT40 levels that determined effects on biomass RGR and alterations in plant morphology. The first criterion followed to classify these species was the detection of an effect on any RGR (Cynosurus echinatus and Aegylops geniculata). Cynosurus echinatus was classified as a sensitive species although $\mathrm{O}_{3}$ exposure induced increases and reductions in some of the assessed parameters. The second criterion adopted was that any alteration in plant performance would be indicative of plant sensitivity. Three groups were defined according to this criterion. The first group involved those species that showed alterations in morphological parameters when exposed to ambient $\mathrm{O}_{3}$ levels ( $V$. myuros, B. hordeaceus and $B$. sterilis). The second group encompassed those species showing morphological changes following their exposure to above ambient $\mathrm{O}_{3}$ levels (Avena sterilis and B. maxima). Ozone exposure did not induce effects on any of the assessed parameters of $A$. triuncialis and $L$. rigidum, thus forming the least sensitive group. As a result, the Gramineae species are ranked as follows:

C. echinatus, A. geniculata $>V$. myuros, B. hordeaceus, B. sterilis $>$ Avena sterilis, B. maxima $>$ A. Triuncialis, L. rigidum

As was the case for legumes, discrepancies were found between this sensitivity ranking and that proposed in Bermejo et al. (2003) for the same species based on foliar injury. The most remarkable disagreement is observed in C. echinatus and V. myuros, that would be most sensitive according to growth but insensitive regarding visible injury.

Some authors have attempted to evaluate whether the C-SR model of plant strategies defined by Grime (1979) could be associated with $\mathrm{O}_{3}$ susceptibility. Reiling and Davison (1992), Selldén and Pleijel (1995), Bungener et al. (1999) and Franzaring et al. (2000) have found that the most sensitive species of their studies presented a high component of $\mathrm{C}$ or $\mathrm{R}$ strategies ( $\mathrm{R} / \mathrm{CR}$ or $\mathrm{CR}$ ) and were the fastest-growing species, showing the greatest RGR in clean air. However, in our experiment plant sensitivity to $\mathrm{O}_{3}$ was neither explained by its RGR values in clean air (Table 2 and 3 ) nor by its CSR classification (data not shown), in agreement with the reports from other authors (Pleijel and Danielsson, 1997; Warwick and Taylor, 1995) that did not find a clear association between these plant traits and $\mathrm{O}_{3}$ sensitivity.

The AOT40 was the exposure index that best explained the observed effects of $\mathrm{O}_{3}$ on the aerial, subterranean or total RGR of grasses and legumes of our experiment, when compared with other indices based on mean, maximum values or accumulated indices using other cut-offs (data not shown). AOT40 was selected to derive equations relating the aerial, subterranean or total RGR of grasses and legumes to $\mathrm{O}_{3}$ exposure (see Fig. 2). In these equations the observed responses were expressed relative to the CFA treatment (100\% growth). Because Leguminosae and Gramineae species showed a great disparity regarding their $\mathrm{O}_{3}$ sensitivity, separate equations were also carried for both taxa. According to the suggestions provided by Ashmore and Franzaring (2003) the two most resistant Leguminosae species were not included in the analysis

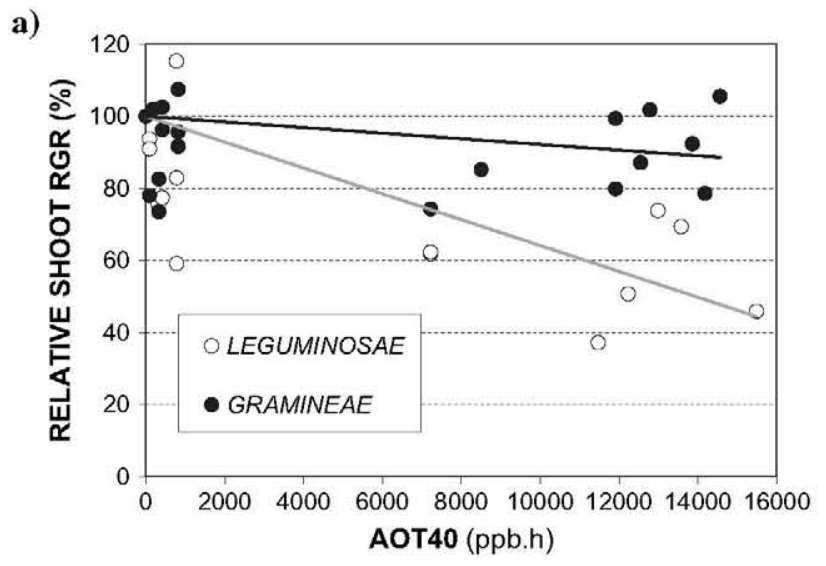

b)

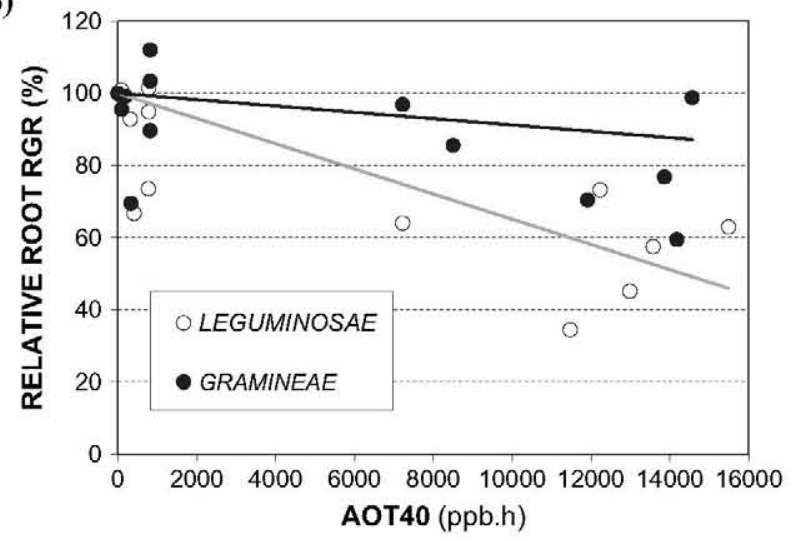

Fig. 2. Growth response of the plants involved in the experiment in relation to ozone exposure (AOT40, ppb h). Models were constructed for Leguminosae plants (lighter line) and Gramineae plants (darker line). (a) Relative shoot RGR; Gramineae: $y=-0.0008 \mathrm{x}+100$ $\left(r^{2}=-0.08, \mathrm{~ns}\right)$; Leguminosae: $y=-0.0036 \mathrm{x}+100\left(r^{2}=0.51\right.$, $p<0.01$ ). (b) Relative root RGR; Gramineae $y=-0.0009 \mathrm{x}+100$ $\left(r^{2}=0.02, \mathrm{~ns}\right) ;$ Leguminosae: $y=-0.0035 \mathrm{x}+100\left(r^{2}=0.64\right.$, $p<0.01)$. 
(see Fig. 2). The best fit was found for the subterranean biomass RGR of legumes plants $\left(r^{2}=0.64\right)$, followed by the total and aerial biomass RGR of this group $\left(r^{2}\right.$ values of 0.57 and 0.51 , respectively). Non-significant relationships between $\mathrm{O}_{3}$ exposure and the performance of Gramineae species were found. Ten per cent reductions in the RGRs of the Leguminosae plants would be expected following exposures to AOT40 values close to $2800 \mathrm{ppb}$ accumulated in a range of 43-67days, in agreement with present critical level for the protection of semi-natural grasslands, $3000 \mathrm{ppb}$ h over a period of up to three months.

In summary, the legumes involved in this screening experiment were more sensitive to $\mathrm{O}_{3}$ than the grass species. Ozone caused detrimental effects on the aerial, subterranean or total biomass of most of the Leguminosae species. Changes in plant morphology were also observed in many legumes following their exposure to $\mathrm{O}_{3}$ levels. Further studies will be carried out to evaluate whether these changes could affect plant $\mathrm{O}_{3}$ uptake. The $\mathrm{O}_{3}$ exposure that induced detrimental effects on the most sensitive species was in the range of the current critical level (Fuhrer et al., 2003). The results of this study indicate that $\mathrm{O}_{3}$ exposure might induce changes in the composition of dehesa grasslands by decreasing the performance of legumes when compared to grasses, and thus affecting the structure and function of these ecosystems and their forage quality. More research is needed to assess the impact of $\mathrm{O}_{3}$ on the competitive ability of these species and its interactive effects with nitrogen and water availability.

\section{Acknowledgements}

This research has been performed under the framework of the UN ECE ICP-Vegetation and it has been funded by the EU BIOSTRESS project, contract EVK2C-1999-00040 and the agreement between the Spanish Ministry of Environment and CIEMAT on "Critical loads and levels". Thanks are given to Modesto Mendoza, for the maintenance of the experimental field and to Dr. César Gómez Campos (ETSI Agrónomos, Madrid), Dr. Francisco González López (Servicio de Investigación y Desarrollo Tecnológico, DG. de Producción, Investigación y Formación Agraria, Consejería de Agricultura y Medio Ambiente, Comunidad de Extremadura) and José Cebolla (ETSI Montes, Madrid) for their kind seed supply.

\section{References}

Alonso, R., Elvira, S., Castillo, F.J., Gimeno, B.S., 2001. Interactive effects of ozone and drought stress on pigments and activities of oxidative enzymes in Pinus halepensis. Plant Cell and Environment 24, 905-916.

Aers, R., Boot, R.G.A., van der Aart, P.J.M., 1991. The relation between above- and below-ground biomass allocation patterns and competitive ability. Oecologia 87, 551-559.

Ashmore, M.R., Ainsworth, N., 1995. The effects of ozone and cutting on the species composition of artificial grassland communities. Functional Ecology 9, 708-712.

Ashmore, M.R., Franzaring, J., 2003. Report from the working group of semi-natural vegetation. In: Karsslson, P.E., Sellden, G., Pleijel, H. (Eds.), Establishing ozone critical levels II. UNECE Workshop Report. IVL Swedish Environmental Institute, University of Göteborg, pp. 23-27.

Ashmore, M.R., Power, S.A., Cousins, D.A., Ainsworth, N., 2003. Effects of ozone on native grass and legumes species: a comparison of responses of individual plants and artificial communities. In: Kärenlämpi, L., Skarby, L. (Eds.), Critical levels for ozone in Europe. UNECE Workshop report. University of Kuopio, Dept. of Ecology and Environmental Science, pp. 104-108.

Azcárate, F.M., Sánchez, A.M., Arqueros, L., Peco, B., 2002. Abundance and habitat segregation in Mediterranean grassland species: the importance of seed weight. Journal of Vegetation Science 13, 159-166.

Balls, G.R., Palmer-Brown, D., Sanders, G.E., 1996. Investigating microclimatic influences on ozone injury on clover (Trifolium subterraneum) using artificial neural networks. New Phytologist $132,271-280$.

Barbo, D.N., Chappelka, A.H., Somers, G.L., Miller-Goodman, M.S., Stolke, K.W., 1998. Diversity of an early successional plant community as influenced by ozone. New Phytologist 138, 291-298.

Bergmann, E., Bender, J., Weigel, H.-J., 1999. Ozone threshold doses and exposure-response relationships for the development of ozone injury symptoms in wild plant species. New Phytologist 144, 423-435.

Bermejo, V., Gimeno, B.S., Sanz, J., de la Torre, D., Gil, J.M., 2003. Assessment of ozone sensitivity of 22 native plant species from Mediterranean annual pastures based on visible injury. Atmospheric Environment 37, 4667-4677.

Bungener, P., Balls, G.R., Nussbaum, S., Geissmann, M., Grub, A., Fuhrer, J., 1999. Leaf injury characteristics of grassland species exposed to ozone in relation to soil moisture condition and vapour pressure deficit. New Phytologist 142, 271-282.

Cooley, D.R., Manning, W.J., 1987. The impact of ozone on assimilate partitioning in plants: a review. Environmental Pollution 47, 95-113.

Davison, A.W., Barnes, J.D., 1998. Effects of ozone on wild plants. New Phytologist 139, 135-151.

El-Khatib, A.A., 2003. The response of some common Egyptian plants to ozone and their use as bioindicators. Environmental Pollution $124,419-428$.

EMEP, 2002. Transboundary acidification, eutrophication and ground level ozone in Europe. EMEP Report 1 and 2/2002. Oslo, Norway, EMEP.

Franzaring, J., Tonniejck, A.E.G., Koijman, A.W.N., Dueck, Th.A., 2000. Growth responses to ozone in plant species from wetlands. Environmental and Experimental Botany 44, 39-48.

Fuhrer, J., Ashmore, M.R., Mills, G., Hayes, F., Davison, A.W., 2003. Ozone critical levels for semi-natural vegetation. In: Karlsson, P.E., Sellden, G., Pleijel, H. (Eds.), Establishing ozone critical levels II. UNECE Workshop Report. IVL Swedish Environmental Institute, Göteborg, Sweden, pp. 183-198.

Fuhrer, J., Shariat-Madari, H., Perler, R., Tschannen, W., Grub, A., 1994. Effects of ozone on managed pasture. II. Yield, species composition, canopy structure and forage quality. Environmental Pollution 83, 317-325.

Gimeno, B.S., Bermejo, V., Reinert, R.A., Zheng, Y., Barnes, J.D., 1999. Adverse effects of ambient ozone on watermelon yield and 
physiology at a rural site in Eastern Spain. New Phytologist 144, 245-260.

Gimeno, B.S., Bermejo, V., Sanz, J., de la Torre, D., Gil, J.M., 2004. Assessment of the effects of ozone exposure and plant competition on the reproductive ability of three therophytic clover species from Iberian pastures. Atmospheric Environment, 2295-2303.

Grime, J.P., 1979. Plant strategies and vegetation processes. Wiley, Chichester.

Hunt, R., 1990. Basic growth analysis. Unwin Hyman, London, U.K.

Karlsson, G., Pleijel, H., Sild, E., Danielsson, H., Selldén, G., Ericson, L., Skärby, L., et al., 1995. Clover Sweden-a national three year study of the effects of tropospheric ozone on Trifolium subterraneum. Water, Air and Soil Pollution 85, 1503-1508.

Madkour, S.A., Laurence, J.A., 2002. Egyptian plant species as new ozone indicators. Environmental Pollution 120, 339-353.

Milliken, G.A., Johnson, D.E., 1992. Designed experiments. Analysis of messy data, vol. I. Chapman \& Hall, New York, USA

Montoya, J.M., Mesón, M.L., Ruiz del Castillo, J., 1988. Una dehesa testigo. La dehesa de Moncalvillo. Serie técnica ${ }^{\circ} 5$. Ministerio de Agricultura Pesca y Alimentación, Madrid, Spain.

Nebel, B., Fuhrer, J., 1994. Inter and intra-specific differences in ozone sensitivity in semi-natural plant communities. Angewandte Botanik 68, 116-121.

Nussbaum, S., Geissmann, M., Fuhrer, J., 1995. Ozone exposure relationships for mixtures of perennial ryegrass and white clover depend on ozone exposure patterns. Atmospheric Environment 29, 989-995.

Palacios, M., Kirchner, F., Martilli, A., Clappier, A., Martín, F., Rodríguez, M.E., 2002. Summer ozone episodes in the Greater
Madrid area. Analysing the ozone response to abatement strategies by modelling. Atmospheric Environment 36, 5323-5333.

Pineda, F.D., de Miguel, J.M., Casado, M.A., Montalvo, J., 2002. Claves para comprender la diversidad biológica y conservar la biodiversidad. In: Pineda, F.D., de Miguel, J.M., Casado, M.A., Montalvo, J. (Eds.), La diversidad biológica en España. Prentice Hall, Madrid, Spain, pp. 7-30.

Plaza, J., Pujadas, M., Artíñano, B., 1997. Formation and transport of the Madrid ozone plume. Journal of Air and Waste Management Association 47, 666-774.

Pleijel, H., Danielsson, H., 1997. Growth of 27 herbs and grasses in relation to ozone exposure and plant strategy. New Phytologist $135,361-367$.

Reiling, K., Davison, A.W., 1992. Effects of a short ozone exposure given at different stages in the development of Plantago major $\mathrm{L}$. New Phytologist 121, 643-647.

San Miguel, A., 1994. La dehesa española. origen, tipología, características y gestión. E.T.S.I.M, Madrid, Spain.

Selldén, G., Pleijel, H., 1995. Photochemical oxidant effects on vegetation-response in relation to plant strategy. Water Air and Soil Pollution 85, 111-122.

Velissariou, D., Davison, A.W., 1994. Ozone effects on important Greek fodder crops. In: Critical levels for ozone. Fuhrer, J., Achermann, B. (Eds.), A UNECE workshop report, Schriftenreihe der FAC No 16, Berne-Liebefeld, pp. 252-255.

Warwick, K., Taylor, R.G., 1995. Contrasting effects of tropospheric ozone on five native herbs which coexist in calcareous grassland. Global Change Biology 1, 143-151. 